\title{
TRONDHEIM \\ NATURAL RADIOCARBON MEASUREMENTS IV
}

\author{
REIDAR NYDAL, KNUT LÖVSETH, KARI E. SKULLERUD, \\ and MARIANNE HOLM
}

Radiological Dating Laboratory, Norwegian Institute of Technology, Trondheim, Norway

\section{INTRODUCTION}

This date list covers mainly the datings done in 1962 and 1963 and is therefore a continuation of our last date list (Trondheim III) .

Counter design-The major number of the samples were measured in a counter with a background of 3.50 counts $/ \mathrm{min}$ and a recent standard net count of 14.20 counts $/ \mathrm{min}$. Some of the samples were measured in the small counter described earlier (Nydal, 1962). This counter has, however, been used mainly in experiments during the past few years.

Pretreatment and purification-In pretreatment of samples and purification of $\mathrm{CO}_{2}$, we have mainly followed our previous procedure (Trondheim III).

Calculation-All dates are calculated in both B.P. and A.D., B.c. scale. In the в.P. scale all dates are calculated from the year 1950, taken as "present". The $\mathrm{C}^{14}$ half-life used is $5568 \mathrm{yr}$; its standard deviation $\pm 30 \mathrm{yr}$ is not included in the standard deviation ( $1 \sigma)$ of the dating results. The NBS recent standard is $95 \%$ of the $\mathrm{C}^{14}$ activity in the oxalic acid, and has been applied since 1960.

Most of the samples are measured for isotopic fractionation, and a correction in the age is applied for deviations more than $1 \%$ from the observed mean value in a large number of measurements. The limit of error in the fractionation analysis is ca. $\pm 1 \%$, and there are possibilities for a maximum error of $30 \mathrm{yr}$ in the age of the samples.

\section{ACKNOWLEDGMENTS}

Sample descriptions have been prepared in collaboration with collectors and submitters of the samples. $\mathrm{C}^{13} / \mathrm{C}^{12}$ ratios are measured by $\mathrm{R}$. Ryhage, Karolinska Institutet, Stockholm. Most of the samples were selected by a committee consisting of Olaf Holtedahl, Department of Geology, University of Oslo, Knut Faegri, Botanic Museum, University of Bergen, and Sverre Marstrander, Videnskapselskapets Oldsaksamling, Trondheim. Special thanks are due to Dr. S. Westin, head of the Physics Department, to Mr. Fred Harald Skogseth for valuable assistance in laboratory work, and to Norges Almenvitenskapelige Forskningsråd for financial support.

\section{SAMPLE DESCRIPTIONS}

I. GEOLOGIC SAMPLES, NORWAY

A. Driftwood, Northern Norway

\section{T-351. Kvalnesberget II, Nordland}

Driftwood (Pinus, id. by E. Mork) from Kvalnes, Dverberg, Nordland 
$\left(69^{\circ} 09^{\prime} \mathrm{N}\right.$ Lat, $16^{\circ} 02^{\prime} \mathrm{E}$ Long), Norway. From sand below peat layer $1 \mathrm{~m}$ thick, alt 4.7 m. Coll. 1961 and subm. 1962 by M. Marthinussen, Univ. of Oslo (collector and submitter of lst nine samples).

\section{St-926. Dverberg Church I, Nordland}

$$
2780 \pm 65
$$

Driftwood $\log$ (Larix, id. by E. Mork) from $4.0 \mathrm{~m}$ above sealevel at Dverberg Church, Andöy, Nordland $\left(69^{\circ} 07^{\prime} \mathrm{N}\right.$ Lat, $15^{\circ} 57^{\prime} \mathrm{E}$ Long), Norway. Underlain by beach sand and covered by ca. $1 \mathrm{~m}$ of peat. Comment: dated at Radioactive Dating Lab., Stockholm.

\section{T-385. Saura II, Nordland}

$$
2710 \pm 90
$$

760 в.с.

Driftwood log (Larix, id. by E. Mork) from surface of sand beneath peat layer $1 \mathrm{~m}$ thick, alt $3.7 \mathrm{~m}$ in Saura, Andöy, Nordland $\left(69^{\circ} 07^{\prime} \mathrm{N}\right.$ Lat, $16^{\circ} 03^{\prime}$ E Long), Norway.

\section{T-350. Saura I, Nordland}

Driftwood $\log$ (Larix, id. by E. Mork) from former seafloor surface beneath peat layer 0.5 to $1.0 \mathrm{~m}$ thick, alt $2.7 \mathrm{~m}$, Saura, Dverberg, Andöy, Nordland ( $69^{\circ} 08^{\prime} \mathrm{N}$ Lat, $15^{\circ} 59^{\prime} \mathrm{E}$ Long), Norway. Comment (M.M.) : driftwood logs are found fairly close to Ramså, where investigations on shoreline displacements have recently been carried out (Marthinussen, 1962, inter al., Pl. 2 ). Datings were made in order to get approx. information of comparatively late movements of shoreline in area. Ages seem to agree, and they also add to the picture of the shore movements. Dates T-350 and T-351 have been marked out in op. cit., Pl. 2.

\section{B. Marine transgression, Northern Norway}

\section{Ramsåprofile I series, Nordland}

Peat samples from deposits of Ramsåprofile I, Ramså, Andöy, Nordland (69 $19^{\circ} \mathrm{N}$ Lat, $16^{\circ} 05^{\prime} \mathrm{E}$ Long), Norway.

\section{T-271 B. Ramså I, ca. 8.55 m below $\quad 10,950 \pm 130$ surface of deposit \\ 9000 в.с.}

Sample, at alt $0.75 \mathrm{~m}$, from same peat layer as T-271 (Trondheim III, p. 165; Marthinussen, 1962, p. 42-43 and 48-49). Comment (M.M.) : T-271 B was dated to verify dating result of T-271, and results are in fairly good agreement (see also T-382, Ramsåprofile Ia this paper). Dates indicate possibility of shore-level lower than present one at Ramså in early Younger Dryas time (cp. op. cit.) .

T-381. Ramså I, ca. 8.45 m below surface of

$9890 \pm 240$ 
in same subsection of profile (Trondheim IJI, p. 165). An underlying subsection that includes peat of T-271 and T-271 B at the top, is different from T-381 and T-294 in that it lacks gyttja and is gravelly. Dates T-271, T-271 B, T-381 and T-294 indicate that transition layer between sub-divisions may also separate deposits of quite different (early Younger Dryas and Preboreal ?) ages.

T-380. Ramså I, ca. $8.70 \mathrm{~m}$ below surface of $\quad 9660 \pm 210$ deposit 7710 B.c.

Scattered straws, probably remnants of vascular plants, from a slope on gravel (see Trondheim III, p. 165), at alt ca. $0.6 \mathrm{~m}$ (below peat layer of T-271 and T-271 B). Material may be primary and actually overlain at first by gravel and then by peat of T-271 (T-271 B), or it may be secondary, e.g. representing younger root filaments penetrating the gravel. Comment (M.M.) : if stratigraphy is interpreted correctly, the date of T-380 is not in harmony with that of T-271 and T-271 B. The possibility of a secondary deposit (by river) may also be considered.

\section{Ramsåprofile Ia series, Nordland}

Sections of this profile and Ramsåprofile I are situated at bank of the rivulet Gårdselva ca. $15 \mathrm{~m}$ apart, and circumstances are virtually identical.

\section{T-382. Ramså Ia, ca. $0.9 \mathrm{~m}$ above sealevel $\quad 10,940 \pm 240$}

Peat from uppermost part of subsection which (in spite of slight height difference) is assumed to be identical with that of Ramsåprofile I, ranging downwards from $0.8 \mathrm{~m}$ above sealevel (Trondheim III, p. 165). Samples above as well as below this have also been coll. Comment (M.M.) : more dates are needed for closer interpretation of profile. Subsection and date (T-382) of profile correspond fairly well with stratigraphic unit and dates (T-271 and T-271 B) of Ramsåprofile I.

\section{T-353. Ramså Ia, ca. $3.25 \mathrm{~m}$ above sealevel $\quad \mathbf{3 4 7 0} \pm 100$}

Shells of Cyprina islandica from gravel layer in a sand body formerly thought to represent a part of Ramsåprofile Ia section. Presumption evidently not correct, since incision cut in sand-gravel masses was not sufficiently deep (horizontally) to reach deposited layers of profile. Comment (M.M.) : the date shows that the shell-bearing gravel and the inclosing sand are younger than Ramsåprofile Ia (and I). An emergence and possibly also a subsequent slight 
T-272. Ramså IIa, ca. $3.90 \mathrm{~m}$ below surface of deposit

$8600 \pm 150$

6650 в.с.

Gyttja (peat) and plant remnants from layer $3 \mathrm{~cm}$ thick, underlain by fragments of rocks in Ramså, Andöy, Nordland $\left(69^{\circ} 10^{\prime} \mathrm{N} \mathrm{Lat,} 16^{\circ} 05^{\prime} \mathrm{E}\right.$ Long), Norway. Coll. 1958 by S. Manum; subm. 1960 by M. Marthinussen. Comment (M.M.) : stratigraphy here as in Ramsåprofile II seems to reveal one transgression. Age of T-272 was expected to be greater than one which corresponds with transgression time concerned. This has been verified by age of T-272 and by age of T-296 (6100 \pm 150 yr в.P.) from Ramsåprofile II (Trondheim III). When sample (T-272) was submitted for dating, no profiles but Ramsåprofile I, apart from present one, were known, and no dates of samples from Ramså had been finished.

\section{Sandstrand shells and whale bones, Northern Norway}

Samples from Sandstrand, Skånland, Troms $\left(68^{\circ} 40^{\prime} \mathrm{N}\right.$ Lat, $16^{\circ} 45^{\prime} \mathrm{E}$ Long), Norway; in clay, underlain by blue clay at base of slope in clay pit near the lake Sandvatnet. Uppermost parts of clay body reach alt of ca. $80 \mathrm{~m}$. Coll. and subm. 1962 by M. Marthinussen.

\section{T-378 B. Sandstrand, whale bones (protein fraction) \\ $11,480 \pm 260$ \\ Alt 72.8 to $73.3 \mathrm{~m}$. \\ T-379. Sandstrand, Mya truncata \\ $11,430 \pm 260$}

Alt $73.5 \mathrm{~m}$.

Comment (M.M.) : previous datings (Marthinussen, 1962, p. $46-47$ and Trondheim III, p. 167) have shown that shore-level in Sandstrand area at times during the Alleröd and probably also during Older Dryas reached at least alt 74 to $75 \mathrm{~m}$. Clay formation, however, indicates somewhat higher shore-line, ca. $80 \mathrm{~m}$. The two dates, which coincide as expected, were done to establish the approx. age of clay as well as of contemporaneous maximum sealevel. Result points to Alleröd. Underlying blue clay may be of greater age; see T-269 (Marthinussen 1962, p. 46 and Trondheim III, p. 167).

\section{Postglacial marine deposits, Southern Norway}

\section{T-390. Bjugnholmen, Sör-Tröndelag \\ $10,310 \pm 180$ 8360 в.C.}

Shells of Saxicava arctica from Bjugnholmen, Örlandet, Sör-Tröndelag $\left(63^{\circ} 45^{\prime} \mathrm{N}\right.$ Lat, $09^{\circ} 34^{\prime} \mathrm{E}$ Long), Norway, from lowest $10 \mathrm{~cm}$ of deposit at NW side of islet, at shore. Coll. 1937 and subm. 1962 by Isak Undås, Bergen. Comment (I.U.) : deposit contains fossils from all late-glacial and postglacial times since deglaciation, and 40 samples were taken, at $10-\mathrm{cm}$ intervals. Dated sample is No. 1 at base of sequence. Date is minimum for deglaciation, probably antedating Örland-moraine or late in Ra-period (Undås, 1963, p. 39).

\section{T-228 A. Florida, Bergen}

$11,700 \pm 150$

9750 B.c.

Shells of Pecten islandicus and Mya truncata from the site of Univ. of 
Bergen, Florida, Bergen $\left(60^{\circ} 25^{\prime} \mathrm{N}\right.$ Lat, $05^{\circ} 20^{\prime} \mathrm{E}$ Long), Norway; found in till. Coll. 1946 by Miss A. Monsen; subm. 1960 by Hans Holtedahl, Univ. of Bergen. Comment (H.H.) : shells are Alleröd and till is supposedly of Younger Dryas age.

\section{T-302. Instevik, Sogn}

$10,250 \pm 440$ 8300 B.C.

Shells, Mya truncata, Saxicava arctica, Pecten islandicus, from Instevik, Kyrkjebö, Sogn og Fjordane (61 $7^{\prime} \mathrm{N}$ Lat, $6^{\circ} 0^{\prime} \mathrm{E}$ Long), Norway. Found next to glaciomarine sand and gravel, alt ca. $20 \mathrm{~m}$, at mouth of small side valley of Sogne Fiord. Coll. 1950 and subm. 1961 by A. Carlsson, Solna, Sweden. Comment (A.C.) : from the main fiord no terminal moraines or icefront deltas are known; in tributary valleys two moraines occur. In an equidistant shoreline diagram the heights of glacial delta surfaces meet a nearly straight line with inclination of $0.90 \mathrm{~m} / \mathrm{km}$. Marine limit level from the Tapes period can be followed on a line, the inclination being $0.26 \mathrm{~m} / \mathrm{km}$. The line first mentioned would then correspond closely to the h-line in the epirogenetic system of shore lines constructed by V. Tanner (1930). Thus, of the systems in which the present author classifies the frontal formations in the Sogne Fiord district, the oldest ought to be simultaneous with the Ra-moraines in the Oslo Fiord. This is verified by the $\mathrm{C}^{14}$ date (Carlsson, 1950, 1960).

\section{T-370. Tveitavatn, Hordaland}

$4090 \pm 150$

\section{0 в.C.}

Diatom mud from bog bordering the lake Tveitavatn on Stord, Hordaland (59 $46^{\prime} \mathrm{N}$ Lat, $05^{\circ} 29^{\prime} \mathrm{E}$ Long), Norway. Coll. by Hiller borer from 3.30 to $3.40 \mathrm{~m}$ below surface of bog formed at SW edge of lake, just behind Cladium mariscus community. Except for sampled layer the series $(5.7 \mathrm{~m})$ consists of coarse detritus gel-mud. Coll. and subm. 1962 by Ulf Hafsten, Univ. of Bergen. Comment (U.H.) : small amounts, less than $6 \%$, of Cladium pollen can be traced down to $5 \mathrm{~m}$ depth, to middle of Zone $\mathrm{V}$ or Boreal period, but at sampled layer the amount increases to more than $20 \%$ and in the next $0.5 \mathrm{~m}$ reaches its postglacial maximum. Rational limit for lime curve lies $0.1 \mathrm{~m}$ below sampled layer and start of cultivation pollen curve takes place immediately above this layer. Sampled layer coincides with highest postglacial values for mixed oak-forest $(\mathrm{QM})$.

\section{E. Botanic samples, Southern Norway}

\section{T-114.}

T-115.

Galdhöpiggen, Oppland

$$
\begin{aligned}
& \mathbf{0} \pm \mathbf{6 0} \\
& \mathbf{0} \pm \mathbf{1 3 5}
\end{aligned}
$$

Large specimens of lichen Umbilicaria rigida (DR) Frey from summit of Galdhöpiggen, alt $2468 \mathrm{~m}$, Jotunheimen, Oppland $\left(61^{\circ} 38^{\prime} \mathrm{N}\right.$ Lat, $08^{\circ} 18^{\prime} \mathrm{E}$ Long), Norway. Coll. and subm. 1959 by E. Dahl, Norges Landbrukshögskole, Vollebekk; dated 1959. Comment (E.D.) : lichens are supposed to grow very slowly in the Arctic. The main part of the lichen weight is due to cell-wall substances; if these are metabolically inactive, as in higher plants, a minimum date might be obtained. Young age obtained suggests that lichen either is younger than supposed, or that cell-wall substances are in metabolically active state. 


\section{F. Geologic Samples from Iceland}

\section{T-343. Kópsvatn, South Iceland}

Shells of Saxicava arctica from glaciomarine silt from E bank of the river Hvitá at Kópsvatn, alt $62 \mathrm{~m}$, district Hrunamannahreppur $\left(64^{\circ} 10^{\prime} \mathrm{N}\right.$ Lat, $20^{\circ} 20^{\prime}$ W Long), South Iceland. Shells (with Balanus sp.) are from base of part of glaciomarine silt overlain by alluvium and loess. Coll. 1941 by Gudmundur Kjartansson; subm. 1962 by Thorleifur Einarsson, Univ. Research Inst., Reykjavík. See comment for T-362 (Kjartansson, 1939).

\section{T-362. Brúará, South Iceland}

Shell fragments of Zirphaea crispata, Mytilus edulis, Saxicava arctica var. rugosa and Balanus sp. from Brúará Bridge, near Spóastadir, South Iceland $\left(64^{\circ} 08^{\prime} \mathrm{N}\right.$ Lat, $20^{\circ} 34^{\prime} \mathrm{W}$ Long), Iceland, found in situ in glaciomarine silt, alt $55 \mathrm{~m}$, outside of lateglacial Búdi-stage end-moraine belt. Comment (Th.E.) : age of highest shorelines (alt 110 to $120 \mathrm{~m}$ ) has been estimated as Postglacial, i.e. Holocene. Pollen analyses have shown that shore lines were found during Icelandic pollen zone A (Betula-free zone), with upper limit of ca. 9000 B.P. Earlier $C^{14}$ dates (W-482, USGS IV, 1958 and W-913, USGS VI, 1961) from peat bed below postglacial Thŕsárlova at Tjórsá Bridge gave ages $8065 \pm 400$ and $8170 \pm 300 \mathrm{yr}$ B.P. respectively, which are in agreement with T-362. Age of shell material from Kópsvatn (T-343, $7970 \pm 180 \mathrm{yr}$ в.P.), $10 \mathrm{~km}$ NE of Brúará Bridge farther inland, seems low.

\section{T-363. Seltjörn, Reykjavík, Iceland}

$3300 \pm 110$ 1350 в.c.

Carex peat from submerged peat in Seltjörn-bay by Reykjavík $\left(64^{\circ} 09^{\prime} \mathrm{N}\right.$ Lat, $22^{\circ} 01^{\prime} \mathrm{W}$ Long), SW Iceland, from beneath basaltic tephra layer K (3 $\mathrm{cm}$ thick) $70 \mathrm{~cm}$ below top of submerged peat layer in inlet of bay Seltjörn on outermost part of peninsula Seltjarnarnes near Reykjavík, alt $0 \mathrm{~m}$. The mean difference between high water and low water level in area is ca. $4 \mathrm{~m}$. Coll. and subm. 1962 by Th. Einarsson. Comment (Th.E.) : from base of peat deposit come two $\mathrm{C}^{14}$ dates $(9030 \pm 280$ yr B.P., Y-249, Yale II, 1955, and $8780 \pm$ 150 yr в.P., H-404/370, Einarsson, 1961, p. 41). These studies indicate that high sealevel at Seltjörn was at least $4.5 \mathrm{~m}$ lower around 9000 B.P. than today. Tephrochronological studies in S and SW Iceland indicate that tephra layer K was produced by an eruption of the volcano Katla in the glacier Mýrdalsjökull, Middle S Iceland, and that tephra layer $\mathrm{K}$ is older than rhyolitic tephra layer $\mathrm{H}_{4}$ (4030 \pm 120 yr B.P., K-140, Tauber, 1961, p. 390), which is older than rhyolitic tephra layer $\mathrm{H}_{3}$ from Hekla $(2720 \pm 130 \mathrm{yr}$ в.P., Y-85, Yale II, 1955, and $2820 \pm 70$ yr B.P., St-813, Stockholm V, 1963). Pollen analyses show that tephra layer $\mathrm{K}$ is contemporaneous with a Betula minimum which seems to have occurred in late Atlantic or early Subboreal time, ca. 5500 to 4500 в.P. The $\mathrm{C}^{14}$ age (T-363) therefore seems low, possibly because of contamination by roots or other sources of younger $\mathrm{C}^{14}$, but it is also possible that tephra layer $\mathrm{K}$ has been misinterpreted (Thórarinsson and others, 1956; Einarsson, 1961). 


\section{T-394. Thorisstadir (ruin), East Iceland}

Carex peat from Thorisstadir, Hrafnkelsdalur, Jökuldalshreppur, S of the river Jökulsá á Dal $\left(65^{\circ} 00^{\prime} \mathrm{N}\right.$ Lat, $15^{\circ} 35^{\prime} \mathrm{W}$ Long $)$, E Iceland. Coll. at $1 \mathrm{~m}$ depth from soil profile at lower contact of thin rhyolitic volcanic tephra layer, alt 370 m. Coll. by S. Thórarinsson; subm. 1962 by Th. Einarsson. Comment (Th.E.) : the tephra layer correlated with tephra layer $\mathrm{H}_{1}$, found in bog and soil profiles in S and N Iceland, marks first eruption of Hekla at beginning of 12th century A.D. (after Icelandic Annal in 1104 A.D.). In soil profile from Thorisstadir have also been found sheep bones a few $\mathrm{cm}$ below this layer. Settlement (landnám) of Iceland took place in yr A.D. 870 to 930 . The $\mathrm{C}^{14}$ date falls close to estimated age.

\section{F. Niger series, Africa}

Lacustrine sediments in areas of East Niger now deserts, have been correlated with long humid period early in the Quaternary; an immense Lake Chad covered large part of Niger, from Ténéré desert in SE towards present Lake Chad. Sediments are between ancient dunes of sand and more recent eolian sands. Six $\mathrm{C}^{14}$ dates from these sediments, all coll. 1954-62 and subm. by H. Faure, Faculté des Sci. de l'Univ. de Dakar, fall between $9240 \pm 130$ and $6900 \pm 150 \mathrm{yr}$ в.P. End of lacustrine period was probably ca. $700 \mathrm{yr}$ B.P. Beginning of period is fixed. The dates indicate that humid periods in the Sahara do not necessarily correspond to European Ice Ages (Faure and others, 1963).

\section{T-279. Kandel Bouzou (No. 3013)}

$6900 \pm 150$

\section{0 в.C.}

Carbonized organic fragments (moss and water plants) from Kandel Bouzou, East Niger ( $15^{\circ} 24^{\prime} \mathrm{N}$ Lat, $10^{\circ} 59^{\prime} \mathrm{E}$ Long), Africa, found in black sandy mud, alt $385 \mathrm{~m}$, probably a former bog beneath sand with Neolithic pottery. Comment (H.F.) : date may indicate the end of a great humid period; it agrees with that of inorganic carbonates (T-361 and T-341).

T-280. Bouloum Gana (No. 3072)

$9150 \pm 200$

7200 в.с.

Diatomite from Bouloum Gana, East Niger $\left(15^{\circ} 01^{\prime} \mathrm{N}\right.$ Lat, $10^{\circ} 37^{\prime} \mathrm{E}$ Long), Africa, from a well, alt $390 \mathrm{~m}$, from sequence of lacustrine sediments.

\section{Agadem series}

Diatomites from Agadem ( $16^{\circ} 50^{\prime} \mathrm{N}$ Lat, $13^{\circ} 20^{\prime} \mathrm{E}$ Long), East Niger, Africa, in lacustrine deposit of clay or mud, locally mixed with limestone containing numerous silicified stems of Phragmites.

\section{T-338 A. Agadem (No. 986)}

Pure diatomite from the principal layer.

T-338 B. Agadem (No. 1020)

Impure diatomite imbedded in mud from a lower position.
$8580 \pm 110$

6630 в.C.

$9240 \pm 130$ 7290 в.C. 


\section{T-341. Kafra (No. 1359)}

Lacustrine limestone from Kafra ( $18^{\circ} 59^{\prime} \mathrm{N}$ Lat, $12^{\circ} 20^{\prime} \mathrm{E}$ Long), East Niger, Africa, with Phragmites. Comment (H.F.) : probably represents the end of lacustrine period. See also comment of T-361.

\section{T-361. Adrar Bous (No. 2177)}

$7310 \pm 120$

5360 в.C.

Lacustrine limestone from Adrar Bous (20 $18^{\prime} \mathrm{N}$ Lat, $09^{\circ} 02^{\prime} \mathrm{E}$ Long), East Niger, Africa, alt $700 \mathrm{~m}$. As the sediments here have a difference of alt of more than $300 \mathrm{~m}$ from those of $\mathrm{E}$ part of Ténéré Fachi, there may have been separate lakes in this district. Comment (H.F.) : date is close to that of T-341 (Kafra). In these two cases limestone represents last lacustrine sediments overlying diatomites. Dates thus probably mark end of humid period in S and central Sahara.

\section{T-340 B. Fachi (No. 1649) \\ $21,350 \pm 350$ \\ 19,400 в.с.}

Lacustrine limestone from Fachi ( $18^{\circ} 03^{\prime} \mathrm{N}$ Lat, $11^{\circ} 40^{\prime} \mathrm{E}$ Long), East Niger, Africa, underlying a layer of diatomite. Limestone was impure with Phragmites. Comment (H.F.) : date may correspond to a low stratigraphic horizon. Assuming rate of sedimentation to be 3 to $5 \mathrm{~m}$ of diatomite in 10,000 to $15,000 \mathrm{yr}$, sample could belong to same lacustrine period as others. Date does not, however, indicate beginning of this period, as diatomite underlies the dated layer.

\section{ARCHAEOLOGIC SAMPLES}

\section{A. Norway}

\section{T-190. Sandve, Rogaland}

Charcoal from Sandve, Brusand, Ogna, Egersund, Rogaland $\left(58^{\circ} 33^{\prime} \mathrm{N}\right.$ Lat, $04^{\circ} 58^{\prime} \mathrm{E}$ Long), Norway, coll. on circular stone-laied cottage-floor approx. $3 \mathrm{~m}$ in diam which was discovered just under peat layer on old shore terrace $25 \mathrm{~m}$ above sealevel. Some waste of flint and potsherds were also found. Locality of finding is ca. $2 \mathrm{~km}$ away from site of T-188 and T-189. Coll. and subm. 1959 by Arne Skjölsvold, Stavanger Mus. Comment (A.S.) : date shows that hunters and fishers in some places still lived under stone-age conditions as late as at transition between Bronze Age and Celtic Iron Age.

\section{Mjölhus series, Rogaland}

Charcoal from habitation layer with potsherd and waste of flint, in rectangular house site (ca. $5 \times 6 \mathrm{~m}$ ) with low stone walls, at Mjölhus, Ogna, Egersund, Rogaland ( $58^{\circ} 32^{\prime} \mathrm{N}$ Lat, $04^{\circ} 55^{\prime} \mathrm{E}$ Long), Norway. House is common type on SW coast of Norway during younger part of Roman Period and during Migration Period. Coll. and subm. 1959 by A. Skjölsvold. Comment (A.S.) : upper and lower layer correspond respectively to last and first phase of settlement. Date shows that this type of house was already fully developed in pre-Roman period. 
T-188. Upper layer

A.D. 200

Coll. between potsherd at depth of 10 to $20 \mathrm{~cm}$ in area of $0.5 \mathrm{~m}^{2}$.

T-189. Lower layer

$2100 \pm 100$

Coll. at depth of 25 to $35 \mathrm{~cm}$ in area of $0.5 \mathrm{~m}^{2}$.

150 B.C.

\section{Holeheia series, Rogaland}

Charcoal from settlement site in Holeheia, Bore, Jaeren, Rogaland $\left(58^{\circ}\right.$ $30^{\prime}$ N Lat, $05^{\circ} 43^{\prime}$ E Long), Norway. Coll. and subm. 1962 by A. Skjölsvold.

\section{T-391. Holeheia I}

$4590 \pm 110$

2640 в.C.

Charcoal from narrow firepit $2.20 \mathrm{~m}$ long, 30 to $40 \mathrm{~cm}$ broad and $20 \mathrm{~cm}$ deep, also containing brittle-burnt stones, and belonging to oldest part of settlement.

\section{T-392. Holeheia II}

$$
\begin{aligned}
& 4400 \pm 100 \\
& 2450 \text { в.C. }
\end{aligned}
$$

Coll. within $1 \mathrm{~m}^{2}$ (sq $4 \mathrm{~d}$ ) in upper part of habitation layer, maximum $10 \mathrm{~cm}$ thick, belonging to youngest part of settlement.

\section{T-331. Lego, Rogaland}

$$
2620 \pm 80
$$$$
670 \text { в.с. }
$$

Charcoal from stake hole No. 2 in outermost edge of rectangular house site, at Lego in Nygård, Sirevåg, Ogna, Rogaland (58 $30^{\prime} \mathrm{N}$ Lat, $05^{\circ} 50^{\prime} \mathrm{E}$ Long), Norway.

\section{T-330. Kvianes, Rogaland}

$$
\begin{gathered}
2660 \pm 80 \\
710 \text { в.с. }
\end{gathered}
$$

Charcoal from Nestangen in Kvianes, Ogna, Rogaland ( $58^{\circ} 32^{\prime}$ N Lat, $05^{\circ} 46^{\prime} \mathrm{E}$ Long), Norway, from $\mathrm{E}$ part of peat wall in house site (made of peat) covering area of $8 \times 6 \mathrm{~m}$ (inner diam) limited by 1.20 to $1.40 \mathrm{~m}$ wide peat walls. Coll. and subm. 1961 by A. Skjölsvold.

\section{T-329. Sandve, Rogaland}

$2600 \pm 60$ $650 \mathrm{B.C}$.

Charcoal from Sandve, Brusand, Ogna, Rogaland (58 $32^{\prime}$ N Lat, $05^{\circ} 48^{\prime}$ E Long), Norway, from fire pit $(1.80 \times 1.30 \mathrm{~m})$ in $\mathrm{SW}$ corner of rectangular house site (ca. $6 \times 10 \mathrm{~m}^{2}$ ) with rounded corners, and depth of 10 to $15 \mathrm{~cm}$. Pit was filled with charcoal and brittle-burnt stones. Coll. 1960 and subm. 1961 by A. Skjölsvold.

\section{Tokke-Vinje series, Telemark}

Charcoal from Stone Age settlement sites near high mountain lakes in Telemark, Norway. Comment (Martens and Hagen, 1961) : tools found on the sites indicate settlers were pure hunters with little or no agricultural contact.

\section{T-216. Finnroi, Telemark}

$5900 \pm 150$ 3950 в.C.

Charcoal from open Stone Age settlement site, alt $950 \mathrm{~m}$, Finnroi, Bitdalsvatn, Rauland, Telemark (59 $50^{\prime}$ N Lat, 07 $53^{\prime} \mathrm{E}$ Long), Norway. Found in cavity in coal layer ca. $25 \mathrm{~cm}$ below turf. Coll. 1959 by A. J. Larsen; 
subm. 1959 by Anders Hagen, Univ. Oldsaksamling, Oslo. Comment (Martens and Hagen, 1961): majority of findings are flint artifacts, but some slate is also present. Refinement of tools dates settlement to Middle Neolithic time.

\section{T-217. Bordalshelleren, Telemark}

$2100 \pm 100$

Charcoal from $35 \mathrm{~cm}$ below surface in habitation layer limited above and below by two arrowheads from youngest part of Stone Age, in rock shelter near Bordalsvatn, Vinje, Telemark ( $59^{\circ} 50^{\prime} \mathrm{N}$ Lat, $07^{\circ} 23^{\prime} \mathrm{E}$ Long), Norway. Coll. 1959 by E. Christensen; subm. 1959 by A. Hagen. Comment (Martens and Hagen, 1961) : archaeological date based on refinement of tools would be early Metal Age, but contamination of younger layers is possible (T-259, Trondheim III, 1962, p. 175).

\section{T-260. Nordre Fjarefit, Telemark}

Charcoal from open settlement Nordre Fjarefit, alt 970 m, at Songa, Vinje, Telemark $\left(59^{\circ} 55^{\prime} \mathrm{N}\right.$ Lat, $07^{\circ} 28^{\prime} \mathrm{E}$ Long), Norway. Habitation layer is mixture of soil and coal below turf. Sample was gathered over area of ca. $1 \mathrm{~m}^{2}$. Coll. 1959 by J. Bleken-Nilssen; subm. 1959 by A. Hagen. Comment (Martens and Hagen, 1961): according to fragments from grinding of flint axes, site dates within Neolithic Period.

\section{Gyrinosvatn series, Buskerud}

Charcoal from areas of 1 to $2 \mathrm{~m}^{2}$ in open Stone Age settlement sites at Gyrinosvatn, Ål, Buskerud ( $60^{\circ} 50^{\prime} \mathrm{N}$ Lat, $08^{\circ} 02^{\prime} \mathrm{E}$ Long), Norway, alt ca. $1100 \mathrm{~m}$. Habitation deposits are thin layers consisting of mixture of earth, sand, and charcoal not more than $10 \mathrm{~cm}$ below turf. Coll. 1959 by T. S. Eikhom; subm. 1959 by A. Hagen. Comment (Martens and Hagen, 1961): findings indicate settlement of pure hunter culture dated archaeologically well within Mesolithic time. Culture has some connection to Fosna Culture found on shores of N Möre, Norway.

\section{T-215. Gyrinos III}

$$
\begin{aligned}
& 8150 \pm 200 \\
& 6200 \text { в.c. } \\
& 6850 \pm 150 \\
& 4900 \text { в.c. } \\
& 6550 \pm 200 \\
& 4600 \text { в.c. }
\end{aligned}
$$

\section{0 в.c.}$$
\text { T-256. Blånut }
$$

\section{T-257. Skyrvenut}

\section{B. Easter Island}

\section{Orongo series}

Charcoal from firepits in ceremonial site of Orongo, Easter Island $\left(27^{\circ}\right.$ 08' S Lat, $109^{\circ} 25^{\prime} \mathrm{W}$ Long) (Heyerdahl and others, 1961, p. 395-396 with references). Coll. 1956 and subm. 1960 by E. N. Ferdon, Jr., Mus. of New Mexico, Santa Fe. $\mathrm{C}^{14}$ dated 1960.

T-193. Orongo site, Complex A 


\section{T-194. Orongo site, Complex B}

RefERENCES

Date lists:

Stockholm V

Trondheim III

USGS IV

USGS VI

Yale II

A.D. 1480

Carlsson, Arne, 1950, Kvartærgeologiske undersökelser i Ytre Sogn med serlig vekt på isarsmeltningen: Cand. real. at Univ. of Oslo, 1950, $65 \mathrm{p}$.

1960, Isavsmältningen i trakterna kring Sognefjorden under sista istiden: Fil. lic, at Univ, of Stockholm, 1960, 125 p.

Einarsson, Th., 1961, Pollenanalytische Untersuchungen zur spät- und postglazialen Klimageschichte Islands: Sonderveröff. des Geol. Inst. der Univ. Köln, no. 6, p. 1-52.

Faure, H., Manguin, E., Nydal, R., 1963, Formations lacustrines du quaternaire supérieur du Niger oriental. Diatomes et ages absolus: Bureau de Recherches Geol. et Minières Bull., no. 3, p. 41-63.

Heyerdahl, Thor, Ferdon, Edwin N., Jr., 1961, Archaeology of Easter Island, v. 1: Gyldendal Norsk Forlag [Oslo], p. 395-396.

Kjartansson, Gudmundur, 1939, Stadier i isens tilbagerykning fra det sydvestislandske lavland: Meddelelser fra dansk geol. forening, v. 9 , no. 4, p. 447.

Martens, Irmelin, and Hagen, Anders, 1961, Arkeologiske undersökelser langs elv og vann: Norske oldfunn, ser. 10 [Oslo], $95 \mathrm{p}$.

Marthinussen, M., 1962, $\mathrm{C}^{14}$-datings referring to shore lines, transgressions, and glacial substages in Northern Norway: Geology of Norway, Norges geol. undersökelse, no. 215, p. $37-67$.

Nydal, R., 1962, Trondheim natural radiocarbon measurements III: Radiocarbon, v. 4, p. 160-181.

1962, Proportional counting technique for radiocarbon measurements: Rev. Sci. Instruments, v. 33 , no. 12 , p. 1313-1320.

Preston, R. S., Person, E., and Deevey, E. S., 1955, Yale natural radiocarbon measurements II: Science, v. 122 , no. 3177, p. 960.

Rubin, Meyer, and Berthold, Sara M., 1961, U. S. Geological Survey radiocarbon dates VI: Radiocarbon, v. 3 , p. 86-98.

Rubin, Meyer, and Alexander, Corrinne, 1958, U. S. Geological Survey radiocarbon dates IV: Am. Jour. Sci., v. 127, p. 1476-1487.

Tanner, V., 1930, Studier över kvartärsystemet i Fennoskandias nordlige delar IV. Om nivåförändringarna etc.: Comm. Geol. Finland Bull., v. 88

Tauber, Henrik, 1961, Danske kulstof-14 dateringsresultater I: Meddelelser fra Dansk Geologisk Forening [Köbenhavn], v. 14, no. 4, p. 387-405.

Thórarinsson, S., Einarsson, Th., and Jónsson, J., 1956, The submerged peat in Seltjörn: Náttúrufræ ingurinn 26 [Reykjavík], p. 179-205.

Undås, I., 1945, Drag av Bergensfeltets kvartærgeologi I: Norsk geol. tidsskr., v. 25, p. $433-448$

1963, Ra-Morenen i Vest-Norge: Bergen, J. W. Eides Forlag A. S., p. 39.

Östlund, H. Göte, and Engstrand, Lars G., 1963, Stockholm natural radiocarbon measurements V: Radiocarbon, v. 5 , p. 211 